\title{
PENGGUNAAN TANAH BAGI PEMAKAMAN DI LAHAN BASAH
}

\author{
Akhmadi Yusran \\ Faculty of Law, Lambung Mangkurat of University \\ Email: akhmadi.yusran@ulm.ac.id
}

\begin{abstract}
Abstrak
Tujuan dari penelitian ini adalah untuk mengetahui kewenangan Pemerintah Kota Banjarmasin terkait pengaturan tempat pemakaman bukan umum (alkah) di Kota Banjarmasin berdasarkan Peraturan Daerah Nomor 7 Tahun 2014 tentang pemakaman dan juga untuk mengetahui status izin terkait pemakaman bukan umum (alkah) berdasarkan Peraturan Daerah Nomor 7 Tahun 2014 tentang pemakaman. Metode penelitian ini memakai penelitian hukum normatif yaitu penelitian yang didasarkan pada bahan hukum yang diperoleh dengan mencoba untuk menganalisis permasalahan hukum yang ada melalui perundang-undangan, literatur, dan bahan lainnya yang bersangkutan dengan masalah yang dikaji. Penelitian ini bersifat deskriptif analitis. Menurut hasil dari penelitian ini menunjukkan bahwa : Pertama, kewenangan Pemerintah Kota Banjarmasin yaitu mengajukan rancangan Perda, menetapkan Perda yang telah mendapat persetujuan bersama DPRD dalam hal ini Pemerintah Kota Banjarmasin telah mengajukan rancangan Perda dan menetapkan Perda yang telah mendapatkan persetujuan DPRD dan terbitlah Peraturan Daerah Nomor 7 Tahun 2014 tentang Pemakaman di Kota Banjarmasin. Kedua, status izin terkait pemakaman bukan umum (alkah), pada dasarnya tidak ada izinnya, bukan hanya izin tanah lahan alkah saja, tidak ada surat menyuratnya juga. Karena tempat pemakaman bukan umum(alkah) tersebut telah ada sejak lama, sudah turun temurun. Jadi, terkait tempat pemakaman bukan umum (alkah) tersebut, apabila sekarang ini ada yang ingin membuat tempat pemakaman bukan umum (alkah) sudah tidak di perbolehkan. Karena, Pemerintah Daerah Kota Banjarmasin telah menyediakan tempat pemakaman yang dijelaskan pada Pasal 4 dan 5 Peraturan Daerah Kota Banjarmasin Nomor 7 tahun 2014 tentang Pemakaman.
\end{abstract}

Kata Kunci: Pengaturan, Alkah, Pemakaman

\section{Abstract}

The purpose of this study is to determine the authority of the Banjarmasin City Government related to the regulation of non-public burial sites in the city of Banjarmasin based on Regional Regulation Number 7 of 2014 concerning funerals and also to determine the status of permits relating to non-public cemetery (alkah) based on Regional Regulation 
Number 72014 about funerals. This research method uses normative legal research that is research based on legal material obtained by trying to analyze existing legal problems through legislation, literature, and other materials concerned with the problem being examined. This research is analytical descriptive.According to the results of this study indicate that: First, the authority of the Banjarmasin City Government is to submit a draft Perda, stipulating a Perda that has been approved by the DPRD in this case the Banjarmasin City Government has submitted a draft Perda and stipulating a Perda that has obtained DPRD approval and the issuance of Regional Regulation Number 7 of 2014 concerning Funerals in the City of Banjarmasin. Secondly, the status of permits relating to burial is not public (alkah), basically there is no permit, not only land permits but also no correspondence. Because burial places are not public (alkah) has been around for a long time, has been passed down for generations. So, related to the burial place is not public (alkah), if at present there is someone who wants to make a burial place not public (alkah) is no longer allowed. Because, the Banjarmasin City Government has provided a burial place as described in Articles 4 and 5 of Banjarmasin City Regulation No. 7 of 2014 concerning Funerals.

Keywords: Arrangement, Alkah, Funeral

\section{PENDAHULUAN}

\section{A. Latar Belakang Masalah}

Banjarmasin adalah kota pesisir yang ramai dari masa ke masa. Kota yang berada di ketinggian 0,16 meter di bawah permukaan laut ini memiliki kondisi alam berpaya-paya yang relatif datar. Dilalui sungai Barito dan Martapura yang beranak pinak membelah kota, masyarakat Banjarmasin menggantungkan kehidupannya pada sungai. Letaknya yang secara geografis berada di $3^{\circ} 16^{\text {ec }} 46^{\text {ceee }}-3^{\circ} 22^{\text {ec }} 54^{\text {ecee }}$ lintang selatan dan $114^{\circ} 31^{\text {ee }} 40^{\text {eeee }}-114^{\circ} 39^{\text {ee }} 55^{\text {ecee }}$ bujur timur, nyaris berada tepat di tengahtengah Indonesia. Posisi ini yang menjadikannya ideal sebagai pelabuhan transit di masa lalu, menghubungkan titik-titik penting dalam jalur perdagangan Nusantara. Kini, ibukota Kalimantan Selatan berpenduduk 675.440 jiwa dengan tingkat kepadatan $6.860 \mathrm{jiwa} / \mathrm{km} 2$ ini kian berkembang seiring dengan dinamika zaman. Pesatnya pembangunan kota yang mengalami pergeseran orientasi ke darat ketimbang air tak pelak menimbulkan berbagai tantangan baru. ${ }^{1}$ Perihal lahan, lahan ialah lingkungan fisik dan biotik yang berkaitan dengan daya dukungnya terhadap kehidupan dan kesejahteraan hidup manusia. Perkembangan penduduk yang

${ }^{1}$ Anonim. Sekilas Kota Banjarmasin. Kreativitas.id/sekilas-kota-banjarmasin/. Diakses tanggal 02 Desember 2018 
semakin meningkat pun membuat area lahan yang semakin sempit di Kota Banjarmasin, misalnya saja area yang menyangkut pemakaman seperti yang kita ketahui bahwa semakin banyaknya penduduk Kota Banjarmasin, maka semakin banyak pula penduduk pada suatu daerah tersebut otomatis menjadi padat penduduk. Dan otomatis juga lahan/area untuk tempat pemakaman itu sendiri menjadi sempit karena semakin banyaknya penduduk Kota Banjarmasin sekarang ini. Khususnya di daerah banjarmasin tidak ada lagi lahan untuk tempat pemakaman tersebut, dan seperti yang kita ketahui pada Peraturan Pemerintah Nomor 9 Tahun 1987 tentan Penyediaan Tanah untuk Keperluan Pemakaman Pada pasal 1 huruf b telah disebutkan "Tempat Pemakaman Bukan Umum adalah area tanah yang disediakan untuk keperluan pemakaman jenazah yang pengelolaannya dilakukan oleh badan sosial dan/atau badan keagamaan. Pada Bab III Pasal 5 ayat (3) di jelaskan sebagai berikut "Pengelolaan Tempat Pemakaman Bukan Umum dilakukan oleh suatu Badan atau Badan Hukum yang bersifat sosial dan/atau bersifat keagamaan dengan izin Kepala Daerah Tingkat II yang bersangkutan dan bagi Daerah Khusus Ibukota jakarta dengan izin Gubernur. Pertumbuhan jumlah penduduk yang meningkat dari tahun ke tahun diiringi dengan meningkatnya jumlah kematian penduduk Kota Banjarmasin. Meningkatnya jumlah kematian menyebabkan permasalahan penyediaan lahan pemakaman yang semakin sempit bagi penduduk yang meninggal karena lahan pemakaman lambat laun akan penuh jika tidak di imbangi dengan penyediaannya. Seperti yang kita ketahui Pemerintah Daerah Kota Banjarmasin telah membuat Peraturan Daerah Nomor 7 Tahun 2014 tentang pemakaman yang di dalam Peraturan Daerah tersebut Pemerintah telah menyediakan lahan Pemerintah Kota Banjarmasin di TPU kilometer 22 Banjarbaru. Tetapi khususnya terkait pemakaman bukan umum (alkah) yang telah ada terlebih dahulu yang telah turun temurun, terkait peizinannya rasanya perlu di pertanyakan lagi apakah sudah ada izin atau belum ada. Terbatasnya tanah sebagai lahan bagi alkah yang dikelola atau disediakan oleh pemerintah daerah disatu sisi, dan keperluan penggunaan lahan pemakaman secara umum, adalah sebuah permasalahan. Dan penggunaan lahan pemakaman bukan umum (alkah) oleh pihak selain pemerintah daerah juga merupakan suatu masalah yang berhadapan dengan kondisi yang secara geografis berhubungan dengan kota Banjarmasin yang berada dibawah permukaan laut dengan memiliki banyak wilayah berair atau rawa, adalah berhubungan dengan tingkat ketersedian lahan bagi tempat pemakaman baik yang disediakan pemerintah daerah maupun pemakaman umum (alkah) yang dikelola oleh pihak selain pemerintah daerah, demikian pula pemakaman pada umumnya yang memerlukan lahan yang representatif bagi sebuah pemakaman. Untuk wilayah Kota Banjarmasin terkait tata kota dan 
juga tentunya terkait tata ruang adalah sebuah keterbatasan dimana sebagian besar lahan berawa juga telah menjadi tempat pemukiman penduduk dengan terbukanya kawasan perumahan atau pemukiman baru, sementara ketersediaan tempat pemakaman menjadi terdesak. Lahan basah (berair dan berawa) idealnya dapat pula berfungsi selain untuk pertanian juga disebabkan karena ketersedian lahan yang kurang bagi penduduk, adalah merupakan sebuah problem bagi pemerintah kota Banjarmasin yang kebijakannya melalui Perda melarang adanya alkah (pemakaman umum) yang dikelola selain dari pemerintah daerah. Ketersedian lahan bagi pemerintah daerah Kota Banjarmasin yang wilayah geografisnya termasuk lahan berair (lahan basah) mengharuskan kebijakan baru dalam penataan kota bagi ketersedian lahan pemakaman. Pemerintah Daerah sudah menjelaskan dalam Peraturan Daerah Nomor 7 Tahun 2014 pada pasal 6 ayat (3) yang berbunyi " melarang adanya alkah keluarga setelah Pemerintah memiliki pemakaman umum yang representatif" dan pasal 6 ayat (4) yang berbunyi "dikecualikan larangan sebagaimana dimaksud ayat (3), untuk alkah yang sudah ada sebelum diberlakukannya Peraturan Daerah ini tetap diperbolehkan. Dari isi pasal tersebut menarik bagi penulis karena dalam Peraturan Daerah tersebut tidak ada dijelaskan bagaimana izin dari sebuah alkah tersebut apakah sudah ada atau belum.

\section{B. Rumusan Masalah}

Berdasarkan latar belakang diatas, peneliti merumuskan masalah sebagai berikut: Bagaimana pelaksanaan kewenangan Pemerintah Kota Banjarmasin terkait pengaturan tempat pemakaman (Alkah) di Kota Banjarmasin berdasarkan Peraturan Daerah Nomor 7 Tahun 2014 tentang pemakaman dan Bagaimana status izin terkait pemakaman bukan umum (Alkah) berdasarkan Peraturan Daerah Nomor 7 Tahun 2014 tentang pemakaman?

\section{METODE PENELITIAN}

Dalam melakukan penelitian ini, maka jenis penelitian yang digunakan adalah penelitian hukum empiris yang menitikberatkan pada penelitian lapangan (field research) untuk mendapatkan data primer, selain itu juga diperlukan penelitian kepustakaan (library research) yang berfungsi untuk melengkapi dan menunjang data yang diperoleh di lapangan. Penelitian kepustakaan ini juga menggunakan data sekunder yang berasal dari 2 (dua) bahan hukum yang dipergunakan dalam penelitian ini yaitu bahan hukum primer dan bahan hukum sekunder.

Bila jenis data yang dikumpulkan adalah data sekunder sebagaimana halnya dalam penelitian hukum normatif, maka studi dokumen 
dipergunakan sebagai alat pengumpulan data. ${ }^{2}$ Berdasarkan data primer dan data sekunder yang terkumpul Peneliti akan melakukan pengkajian dan analisa sehingga dapat ditemukan tujuan khusus dari penelitian ini.

\section{Sifat Penelitian}

Hasil penelitian ini bersifat deskriptif analitis, karena dari penelitian ini diharapkan akan diperoleh gambaran secara menyeluruh (holistik), mendalam dan sistematis tentang Penggunaan Tanah Bagi Pemakaman Di Lahan Basah Di Kota Banjarmasin. Dikatakan analitis, karena kemudian akan dilakukan analisis terhadap berbagai aspek yang diteliti, selain menggambarkan secara jelas tentang asas-asas hukum, kaedah hukum, berbagai pengertian hukum, hasil penelitian di lapangan yang berkaitan dengan penelitian yang dilakukan.

\section{Bahan atau Materi Penelitian}

Untuk penelitian kepustakaan materi penelitian dalam penelitian ini ada 2 (dua) macam, yaitu:

a. Untuk Penelitian Kepustakaan

1) Bahan Hukum Primer terdiri dari: peraturan perundangundangan mengenai Penggunaan Tanah Bagi Pemakaman Di Lahan Basah Di Kota Banjarmasin;

2) Bahan Hukum Sekunder terdiri dari: buku-buku, diktat, jurnal hukum, majalah hukum, hasil penelitian dan di internet;

\section{b. Untuk Penelitian Lapangan}

Data yang dikumpulkan dari penelitian lapangan adalah data primer tentang segala sesuatu yang ada kaitannya dengan masalah yang diteliti Dalam memperoleh data tersebut ditentukan wilayah dan obyek penelitian.

1) Wilayah Penelitian

Penelitian ini dilakukan di wilayah hukum Kota Banjarmasin.

2) Obyek Penelitian

Sebagai obyek penelitian dalam penelitian ini Penggunaan Tanah Bagi Pemakaman Di Lahan Basah Di Kota Banjarmasin.

\section{c. Jalannya Penelitian}

Dalam pelaksanaan penelitian lapangan ini langkah-langkah ditempuh terdiri dari 3 (tiga) tahap, sebagai berikut:

1. Tahap Persiapan: Pada tahap ini dimulai dengan pengumpulan bahan kepustakaan, dilanjutkan dengan penyusunan usulan penelitian.

${ }^{2}$ Maria SW Soemardjono. 1989. Pedoman Pembuatan Usulan Penelitian, Yogyakarta: Fakultas Hukum Universitas Gadjah Mada, hlm. 23. 
2. Tahap Pelaksanaan: Pada tahap ini penelitian kepustakaan dilakukan dengan maksud pengumpulan data dan pengkajian terhadap data sekunder, yang meliputi bahan hukum primer dan bahan hukum sekunder. Dalam penelitian lapangan dilakukan pengumpulan data primer melalui observasi.

3. Tahap Penyelesaian: Pada tahap ini dilakukan berbagai kegiatan yaitu penulisan laporan awal hasil penelitian dan menganalisis yang dilanjutkan dengan konsultasi serta perbaikan dan diakhiri dengan laporan akhir.

\section{d. Analisis Data}

Analisis yang digunakan dalam penelitian ini adalah metode kualitatif. Data yang telah terkumpul baik dari hasil observasi maupun hasil dari studi dokumen dikelompokkan sesuai dengan permasalahan yang akan dibahas. Data tersebut kemudian ditafsirkan dan dianalisis guna mendapatkan kejelasan (pemecahan dari masalah yang akan dibahas). Teknik analisis dilakukan secara interpretasi, yaitu data diinterpretasikan dan dijabarkan dengan mendasarkan pada suatu norma-norma dan teori-teori ilmu hukum yang berlaku, sehingga pengambilan keputusan yang menyimpang seminimal mungkin dapat dihindari.

\section{PEMBAHASAN}

\section{Pelaksanaan Kewenangan Pemerintah Kota Banjarmasin Terkait Pengaturan Tempat Pemakaman (Alkah) Di Kota Banjarmasin}

Undang-Undang Republik Indonesia Nomor 23 Tahun 2014 tentang Pemerintahan Daerah pada Pasal 1 butir 2 menyebutkan "Pemerintahan Daerah adalah penyelenggaraan urusan pemerintahan oleh Pemerintah Daerah dan Dewan Perwakilan Rakyat Daerah menurut asas otonomi dan tugas pembantuan dengan prinsip otonomi seluas-luasnya dalam sistem dan prinsip Negara Kesatuan Republik Indonesia sebagaimana dimaksud dalam Undang-Undang Dasar Negara Republik Indonesia Tahun 1945." Dan pada Pasal 1 butir 3 menyebutkan " Pemerintah Daerah adalah kepala daerah sebagai unsur penyelenggara Pemerintahan Daerah yang memimpin pelaksanaan urusan pemerintahan yang menjadi kewenangan daerah otonom."

Dalam Pasal 18 UUD 1945 dikatakan bahwa "Pembagian daerah Indonesia atas daerah besar dan kecil, dengan bentuk susunan pemerintahannya ditetapkan dengan undang-undang, dengan memandang dan mengingat dasar permusyawaratan dalam sistem pemerintahan negara, dan hak-hak asal usul dalam daerah-daerah yang bersifat istimewa."

Penjelasan Pasal 18 UUD 1945 menerangkan bahwa karena negara Indonesia itu adalah suatu negara kesatuan, Indonesia tidak akan 
mempunyai daerah di dalam lingkungannya yang juga berbentuk negara. Wilayah Indonesia dibagi menjadi daerah-daerah provinsi dan daerah provinsi dibagi pula menjadi daerah yang lebih kecil. Daerah-daerah itu bersifat otonom atau bersifat administratif belaka, semuanya menurut aturan yang akan ditetapkan dengan undang-undang. Di daerah-daerah yang bersifat otonom diadakan badan perwakilan daerah, karena di daerah pun pemerintah akan bersendikan dasar permusyawaratan.

Otonomi daerah yang pada dasarnya dilaksanakan berdasarkan asas desentralisasi, dekonsentrasi dan tugas pembantuan (medebewind) dimana asas desentralisasi adalah asas yang menyatakan penyerahan sejumlah urusan pemerintahan dari Pemerintah Pusat atau dari pemerintah daerah tingkat yang lebih tinggi kepada pemerintah daerah tingkat yang lebih rendah sehingga menjadi urusan rumah tangga daerah itu. Dengan demikian, prakarsa, wewenang, dan tanggung jawab mengenai urusan-urusan yang diserahkan tadi sepenuhnya menjadi tanggung jawab daerah itu, baik mengenai politik kebijaksanaan, perencanaan, dan pelaksanaannya maupun mengenai segi-segi pembiayaannya. Perangkat pelaksanaannya adalah perangkat daerah sendiri. ${ }^{3}$

Asas Dekonsentrasi adalah asas yang menyatakan pelimpahan wewenang dari Pemerintah Pusat atau kepala wilayah atau kepala instansi vertikal tingkat yang lebih tinggi kepada pejabat-pejabatnya di daerah. Tanggung jawab tetap ada pada Pemerintah Pusat. Baik perencanaan dan pelaksanaannya maupun pembiayaannya tetap menjadi tanggung jawab Pemerintah Pusat. Unsur pelaksanaannya dikoordinasikan oleh kepala daerah dalam kedudukannya selaku wakil Pemerintah Pusat.

Latar belakang diadakannya sistem dekosentrasi ialah bahwa tidak semua urusan Pemerintahan Pusat dapat diserahkan kepada Pemerintah daerah menurut asas desentralisasi.

Faktor-faktor yang mempengaruhi pelaksanaan otonomi daerah :

(1) Manusia pelaksananya harus baik;

(2) Keuangan harus cukup dan baik;

(3) Peralatannya harus cukup dan baik;

(4) Organisasi dan Manajemennya harus baik.

Kewenangan Pemerintah Kota Banjarmasin yaitu mengajukan rancangan Perda, menetapkan Perda yang telah mendapat persetujuan bersama DPRD dalam hal ini Pemerintah Kota Banjarmasin telah mengajukan rancangan Perda dan menetapkan Perda yang telah mendapatkan persetujuan DPRD dan terbitlah Peraturan Daerah Nomor 7 Tahun 2014 tentang Pemakaman di Kota Banjarmasin.

${ }^{3}$ Ibid, hlm. 3 . 


\section{Status Izin Terkait Pemakaman Bukan Umum (Alkah) Berdasarkan Peraturan Daerah Nomor 7 Tahun 2014 Tentang Pemakaman}

Keabsahan tindak pemerintahan tunduk pada dua tolok ukur, yaitu hukum tertulis dan hukum tidak tertulis. Pada dewasa ini perhatian cukup besar diarahkan kepada hukum tidak tertulis berupa asas-asas umum pemerintahan yang baik, bahkan asas ini telah dipositifkan melalui ketentuan Pasal 53 ayat (2) huruf b Undang-undang No. 5 Tahun 1986 tentang Peradilan Tata Usaha Negara sebagaimana dirubah dengan UU No. 9 Tahun 2004 dan Perubahan kedua dengan UU No. 51 Tahun 2009, mengingat sifat, hakekat dan keterbatasan hukum tertulis seperti peraturan perundang-undangan. Dalam Hukum Administrasi, izin merupakan instrumen yuridis yang digunakan oleh pemerintah untuk mempengaruhi para warga agar mau mengikuti cara yang dianjurkan guna mencapai suatu tujuan konkrit. Sebagai suatu instrument hukum, izin berfungsi sebagai ujung tombak atau alat yang bertujuan untuk mengarahkan, mengendalikan, merekayasa, dan merancang masyarakat adil makmur. Melalui izin dapat diketahui bagaimana gambaran masyarakat adil makmur itu terwujud, yang berarti persyaratan-persyaratan yang terkandung dalam izin merupakan pengendali dalam memfungsikan izin itu sendiri. Dalam pemahaman ilmu hukum Instrumen perizinan yang dikeluarkan oleh Badan atau Pejabat Tata Usaha Negara digunakan untuk:

1) Mengarahkan atau mengendalikan (sturen) aktivitas tertentu;

2) mencegah bahaya yang dapat ditimbulkan oleh aktivitas tertentu;

3) melindungi obyek-obyek tertentu;

4) mengatur distribusi benda langka;

5) seleksi orang dan atau aktivitas tertentu.

Dengan kegunaan yang demikian itu, setiap izin pada dasarnya membatasi kebebasan individu. Dengan demikian wewenang membatasi hendaknya tidak melanggar prinsip dasar negara hukum, yaitu asas legalitas. Atas dasar teori demikian itu, wewenang memberikan izin adalah wewenang yang diberikan oleh peraturan perundang-undangan. Wewenang itu diberikan untuk mencapai tujuan konkrit. Aspek yuridis perizinan meliputi: (1) Larangan untuk melakukan suatu aktivitas tanpa izin, (2) wewenang untuk memberi izin dari Badan atau Pejabat Tata Usaha Negara.

Larangan dan wewenang untuk menyimpang dari apa yang seyogyanya dilakukan harus ditegaskan dalam peraturan perundangundangan. Larangan dirumuskan dalam norma larangan, bukan bentuk norma perintah. Dengan demikian pelanggaran atas larangan itu lazimnya dikaitkan dengan sanksi, baik sanksi administrasi maupun sanksi pidana. Ruang lingkup dan batas batas mengenai larangan tergantung pada uraian 
tingkah laku yang dilarang. Formulasi larangan dapat berupa larangan umum maupun larangan yang memuat ketentuan-ketentuan khusus, misalnya dilarang mendirikan bangunan tanpa izin (larangan umum), sedangkan larangan khusus misalnya: Dilarang membuang limbah kimia (dengan atau tanpa pembukus) di atas atau di dalam tanah. Wewenang memberi izin pada dasarnya merupakan wewenang publik. Suatu wewenang publik adalah wewenang yang berdasarkan Hukum Tata Negara dan atau Hukum Administrasi Negara. ${ }^{4}$

Dalam Peraturan Pemerintah Nomor 15 Tahun 2010 tentang penyelenggaraan penataan ruang, pada Pasal 1 butir 17 menyatakan " Izin pemanfaatan ruang adalah izin yang dipersyaratkan dalam kegiatan pemanfaatan ruang sesuai dengan ketentuan peraturan perundang-undangan. Terkait dengan izin pemakaman berarti penataan ruang harus benar-benar diatur dan di tata rapi. Sedangkan, Peraturan Daerah Kota Banjarmasin Nomor 7 Tahun 2014 tentang pemakaman. Pada Pasal 1 butir 8 menyebutkan " Tempat pemakaman bukan umum adalah areal tanah yang disediakan untuk keperluan pemakaman jenazah yang pengelolaannya dilakukan oleh badan sosial dan/atau badan keagamaan. Jadi, dari Peraturan Daerah ini telah diatur tentang tempat pemakaman bukan umum (alkah), akan tetapi tentang status izin tempat pemakamn bukan umum (alkah) tersebut tidak dijelaskan bagaimana tentang status izin dari tempat pemakaman bukan umum (alkah) tersebut.

Status izin tempat pemakaman bukan umum (alkah), umumnya tempat pemakaman bukan umum (alkah) tersebut adalah tanah wakaf yang dipergunakan untuk tempat pemakaman, dengan status hak milik. Rata-rata dari alkah keluarga tersebut tidak ada izinnya, tidak ada surat- menyuratnya juga. Karena tempat pemakaman bukan umum (alkah) tersebut sudah turun temurun. Demikian pula, dalam Peraturan Daerah Kota Banjarmasin pada Pasal 26 ayat (1) menyebutkan "tempat pemakaman bukan umum di kelola oleh badan atau badan hukum yang bersifat sosial dan/atau bersifat keagamaan", Pada Pasal 28 ayat (2) menyebutkan "Pengelolaan sebagaimana dimaksud pada ayat (1) berdasarkan izin walikota. Dan pada pasal 28 ayat (1) menyebutkan "Setiap pengelolaan pemakaman bukan umum dalam daerah dapat memberlakukan pemungutan kepada ahli waris atau pertanggungajawabannya untuk pelaksanaan pengelolaan. Terkait tempat pemakaman bukan umum (alkah) tersebut, apabila sekarang ini ada yang ingin membuat tempat pemakaman bukan umum (alkah) sudah tidak di perbolehkan, karena Pemerintah Daerah Kota Banjarmasin telah

\footnotetext{
${ }^{4}$ Nur Asiyah. Strategi Implementasi Perizinan dan Sanksi Administratif Sebagai Pembatasan Terhadap Kebebasan Bertindak. 2017. Artikel dalam "Jurnal Hukum Samudra Keadilan”. No. 1. Vol. 12. Januari-Juni, hlm. 124-125.
} 
mengatur dalam Peraturan Daerah Nomor 7 tahun 2014 tentang Pemakaman. Terdapat dalam Pasal 4 ayat (1) menyebutkan "Pemerintah Daerah menyediakan tanah untuk tempat pemakaman bukan umum" dan pada Pasal 4 ayat (2) menyebutkan "Orang atau badan dapat menyediakan tanah untuk pemakaman bukan umum". Tapi, dikecualikan alkah yang telah ada terlebih dahulu sebelum diberlakukan peraturan daerah tersebut tetap diperbolehkan.

\section{KESIMPULAN}

Undang-Undang Republik Indonesia Nomor 23 Tahun 2014 tentang Pemerintahan Daerah telah mengatur tentang Penyelenggara Pemerintahan Daerah. Penyelenggara Pemerintahan Daerah provinsi dan kabupaten/kota terdiri atas kepala daerah dan DPRD dibantu oleh Perangkat Daerah. Setiap Daerah dipimpin oleh Kepala Pemerintahan Daerah yang disebut kepala daerah, yang dimaksud Kepala Daerah untuk provinsi ialah disebut Gubernur, untuk Daerah kabupaten disebut bupati, dan untuk daerah kota disebut walikota. Adapun yang menjadi kewenangan Pemerintah Kota Banjarmasin ialah : Mengajukan rancangan Peraturan Daerah, menetapkan Peraturan Daerah yang telah mendapat persetujuan bersama DPRD dalam hal ini Pemerintah Kota Banjarmasin telah mengajukan rancangan Perda dan menetapkan Perda yang telah mendapatkan persetujuan DPRD dan terbitlah Peraturan Daerah Kota Banjarmasin Nomor 7 Tahun 2014 tentang Pemakaman.

Status izin tempat pemakaman bukan umum (alkah), umumnya tempat pemakamaan bukan umum (alkah) tersebut adalah tanah wakaf, yang dipergunakan untuk tempat pemakaman dengan status hak milik, rata-rata alkah keluarga tersebut tidak ada izinnya, tidak ada surat-menyuratnya juga. Terkait tempat pemakaman bukan umum (alkah) tersebut, apabila sekarang ini ada yang ingin membuat tempat pemakaman bukan umum (alkah) sudah tidak di perbolehkan, karena Pemerintah Daerah Kota Banjarmasin telah mengatur dalam Peraturan Daerah Nomor 7 tahun 2014 tentang Pemakaman. Terdapat dalam Pasal 4 ayat (1) menyebutkan "Pemerintah Daerah menyediakan tanah untuk tempat pemakaman bukan umum", pada Pasal 4 ayat (2) menyebutkan "Orang atau badan dapat menyediakan tanah untuk pemakaman bukan umum" pada Pasal 4 ayat (3) menyebutkan “ Penyediaan tanah untuk pemakaman sebagaimana dimaksud pada ayat (1) dan ayat (2) dibuat dengan desain arsitektur alami dan bebatuan, blok, akses jalan setapak antar blok dan antar petak makam serta identitas tempat pemakaman pada layar depan pemakaman". Dan pada Pasal 5 menyebutkan "Penyediaan tanah untuk tempat pemakaman sebagaimana dimaksud dalam Pasal 4 berdasarkan penunjukan dan penetapan Walikota termasuk tanah 
wakaf yang disediakan untuk tempat pemakaman. Tapi, khusus alkah yang telah ada terlebih dahulu sebelum diberlakukan peraturan daerah tersebut tetap diperbolehkan, karena alkah tersebut sudah ada sejak lama.

\section{DAFTAR PUSTAKA}

\section{Buku}

Atmojosudirdjo, Prajudi. 1981. Hukum Administrasi Negara. Jakarta:

Ghalia Indonesia.

Direktorat Jenderal Peraturan Perundang-undangan Departemen Hukum dan Hak Asasi Manusia, Tim Direktorat Fasilitasi Perancangan Peraturan Daerah. 2009. Panduan Praktis Memahami Perancangan Peraturan Daerah. Jakarta : Direktorat Jenderal Peraturan PerundangUndangan Departemen Hukum dan Hak Asasi Manusia R.I.

Gadjong, A., \& Salim, A. (2004). Pemerintahan Daerah Kajian Politik dan Hukum. Jakarta: Ghalia Indonesia.

Gie, The Liang. 1968. Kamus Administrasi. Jakarta : Gunung Agung.

Hidjaz, Kamal. 2010. Efektivitas Penyelenggaraan Kewenangan Dalam Sistem Pemerintahan Daerah di Indonesia. Makassar: Pustaka Refleksi.

HR, Ridwan. 2011. Hukum Administrasi. Jakarta : RajaGrafindo.

J.B.J.M, ten Berge dan N.M. Spelt. Pengantar Hukum Perizinan. Surabaya: Yuridika.

Kansil, C.S.T dan Christine S.T Kansil, Pemerintahan Daerah di Indonesia Hukum Administrasi Daerah. Jakarta : Sinar Grafika.

Kaho, Josef Riwu. 2005. Prospek Otonomi Daerah di Negara Republik Indonesia. Jakarta: RajaGrafindo.

Sunggono, Bambang. 2013. Metode Penelitian Hukum. Jakarta : Raja Grafindo Persada.

Sri Mamudji, Soerjono Soekanto. 1990. Penelitian Hukum Normatif Suatu Tujuan Singkat. Jakarta : Rajawali. 